\title{
Characterization, conservation and sustainability of endangered animal breeds in Campania (Southern Italy)
}

\author{
Vincenzo Peretti ${ }^{1}$, Francesca Ciotola ${ }^{2}$, Leopoldo lannuzzi ${ }^{3^{*}}$ \\ ${ }^{1}$ Department of Veterinary Medicine and Animal Production, University Federico II, Naples, Italy \\ ${ }^{2}$ Francesca Ciotola, Department of Health Science, University of Catanzaro, Catanzaro, Italy \\ ${ }^{3}$ National Research Council, Institute of Animal Production Systems in Mediterranean Environments, Naples, Italy; \\ *Corresponding Author: leopoldo.iannuzzi@ispaam.cnr.it
}

Received 6 April 2013; revised 6 May 2013; accepted 21 May 2013

Copyright (C) 2013 Vincenzo Peretti et al. This is an open access article distributed under the Creative Commons Attribution License, which permits unrestricted use, distribution, and reproduction in any medium, provided the original work is properly cited.

\begin{abstract}
Conservation of such animal genetic resources and sustainable development of their products seems to be one of the most important steps to be taken to save endangered animal breeds from the widespread use of cosmopolitan and more productive breeds. Indeed, the protection and conservation of biodiversity of animal breeds adapted to particular environmental conditions is essential to prevent irreversible erosion of genes and gene combinations. A special project to characterize and conserve eight endangered breeds of various animal species raised in Campania (southern-Italy) is reported in this paper along detailed descriptions of all breeds. Some strategies for their characterization and conservation are reported and discussed.
\end{abstract}

Keywords: Endangered Breed; Livestock; Conservation

\section{INTRODUCTION}

As established in the global plan of action for animal genetic resources adopted through the Interlaken Declaration in 2007

(http://www.fao.org/docrep/010/a1404e/a1404e00.htm), the sustainability, development and conservation of the world's livestock genetic resources are of crucial importance for both agriculture and animal productions, as well as for environmental protection [1]. Indeed, more than 7000 domestic animal breeds have been developed by farmers and pastoralists in various environments since the first livestock species were domesticated about 12,000 years ago. These breeds now represent unique combinations of genes. Conservation of such animal genetic resources and sustainable development of their products seems to be one of the most important steps to be taken to save endangered animal breeds from the widespread use of cosmopolitan and more productive breeds, the latter often offering a poor quality product. Indeed, the protection and conservation of biodiversity of animal breeds adapted to particular environmental conditions is essential to prevent irreversible erosion of genes and gene combinations [2,3]. Their conservation aims to avoid not only the permanent loss of genotypes, but also to enhance the adaptive capacity of such individuals to specific ecosystems, the production of specific characteristics of these breeds, and the economic and cultural heritage constituted by such breeds, particularly those found in the southern Italian region of Campania. Few countries in the world, and certainly none in Europe, are as varied as Italy despite its relatively small land area in geology, morphology, altitude and climate. Such a variety of conditions, together with the fragmented history of its city-states, duchies, kingdoms, dialects and cultures, have created the conditions for the presence of an abundance of plant species and varieties as well as animal breeds. Many such animal breeds, due to the spread of both techniques and breeds most suited to intensive production, are now lost or endangered.

The importance of protecting and preserving endangered breeds lies in their ability, compared to cosmopolitan breeds, to produce in hostile environments by making optimal use of local resources. In Campania a special regional project, PSR 214 e2, called "RARECA" (Indigenous Animal Breeds at Risk of Extinction in Campania) is seeking to characterize, promote and conserve some endangered local animal breeds. The indigenous 
genetic types (TGA) found in this region, listed in birth registers or studbooks (all managed by the Italian Breeders Association-AIA), comprise the following animal breeds: the Agerolese cattle, the Laticauda and Bagnolese sheep, the Cilentana goat, the Casertano pig, the Salernitano, Napoletano and Persano horses. This study covers their origin and current populations, breeding areas and some initiatives to promote them by marketing typical products, as well as characterizing and conserving them using several scientific approaches.

\section{ENDANGERED BREEDS OF CAMPANIA}

\subsection{Agerolese Cattle}

Origins. The Agerolese dairy cow, now linked uniquely to the well-known "Provolone del Monaco" Protected Denomination of Origin (PDO), originates in the area of the Lattari mountains and the Sorrento Peninsula. In these places the Picentini people, defeated by the Romans in 264 BC, settled with their cattle initially in difficult, mostly wooded terrain, later adapted to farmland for dairy herds. For their exceptional production of milk, the mountains were called Mons Lactarius. Following numerous crosses with breeds introduced in subsequent centuries (Bretonne, Bruna Alpina, Jersey and Friesian), a dairy breed was selected and described at the beginning of the 20th century as a good milking cow, yielding from 17 to 18 liters of milk per day in a good season. The uniqueness of the Agerolese cattle breed is the result of centuries of selection, modulated by an adverse environment and the absence of pastures, to produce a fair amount of milk with excellent organoleptic characteristics despite poor nutrition often based on "brushwood". The typical characteristics of this raw material skillfully transformed by the cheesemakers of the Sorrento Peninsula and Lattari mountains guarantees the uniqueness of the PDO "Provolone del Monaco".

Breeding area. It is raised exclusively in the province of Naples in the area of the Lattari Mountains and Sorrento Peninsula.

Population. To date, the animals listed in the official register comprise 156 adults, including 128 females and 28 males, although the population is larger (101 subjects are pending examination by breed experts).

Morphological traits. Of medium size with smooth trunk, coat is brown with lighter shade in the abdominal region in females (Figure 1) and with a characteristic black clearer line (mills) in males. The head is light, with a concave profile, large eyes and bright, mediumsized ears, a black muzzle surrounded by a white halo, mediumlength horns, curved in bulls, direct side up and forward in cows. The neck is slightly reduced with a dewlap; proportioned limbs, muscular thighs, strong feet with black

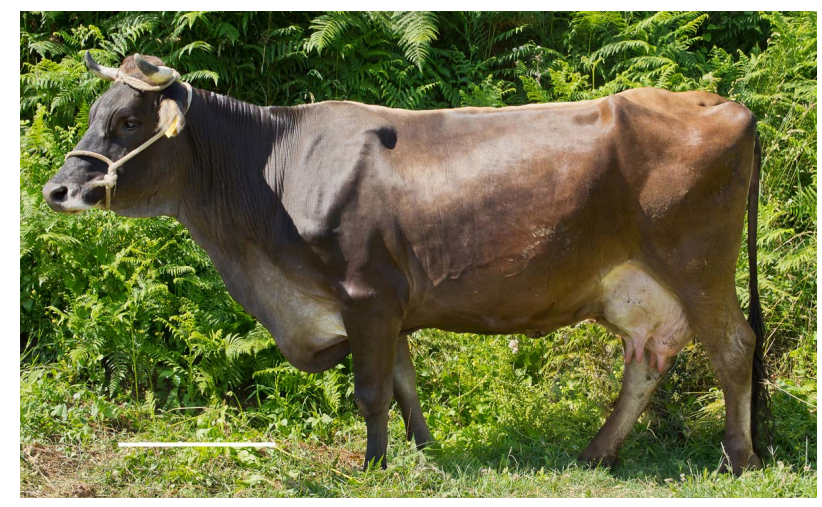

Figure 1. A female cow of "Agerolese" cattle breed. Bar $=50$ $\mathrm{cm}$.

claws. The udder is well developed.

Suitability. Although a dual-purpose breed (milk and meat), it is used almost exclusively for milk production, which is around 20 liters per day with a protein and fat content over 3.5\%, extensively processed into butter and various cheese types such as mozzarella (stretched curd) and caciocavallo and the renowned PDO Provolone del Monaco. To obtain this PDO product at least $20 \%$ of milk must be from the Agerolese cattle breed.

\subsection{Laticauda Sheep}

Origins. The Laticauda breeds comes from interspecific hybridization carried out over a long time, in a discontinuous manner, between the local Apennine sheep population and Barbary sheep of north African origin, with which it shares several characteristics, especially the broad tail, bulky and broad in its first section, characteristics which gave the breed its name: Laticauda comes from the Latin meaning "broad tail". The breed is currently raised in the provinces of Benevento, Avellino and Caserta, although some nuclei are also present outside Campania in the provinces of Cosenza, Matera, Catanzaro and Campoba sso.

Population. Currently there are 84 farms in Campania rearing Laticauda sheep under the auspices of the National Livestock Association (ASSONAPA) (Table 1).

Livestock practice. The herds consist mainly of small numbers (up to a few tens of animals), often mixed with other selected breeds such as Comisana and Delle Langhe, with the exception of the few companies where there is a kind of semi-intensive breeding. The flocks at night and on rainy days are kept in shelters. Feeding from spring to autumn is directly on the farm's pastures and integrated with feedstuff, while in the winter it consists of hay and mixture prepared in the farm.

Morphological traits. A large sheep breed with a live weight of 90 - $100 \mathrm{~kg}$ (rams) and 60 - $70 \mathrm{~kg}$ (ewes) (Figure 2). It has a heavy head with a ram's profile. Ears are medium-sized, flat and directed laterally. The horns are 
Table 1. Numbers of Laticauda sheep in Campania by province.

\begin{tabular}{rccc}
\hline Province & Ewes $(\mathrm{N})$ & Rams & Total \\
\hline Avellino & 934 & 50 & 984 \\
Benevento & 1922 & 101 & 2023 \\
Caserta & 517 & 225 & 742 \\
Napoli & 5 & 1 & 6 \\
TOTAL & 3378 & 377 & 3755 \\
\hline
\end{tabular}

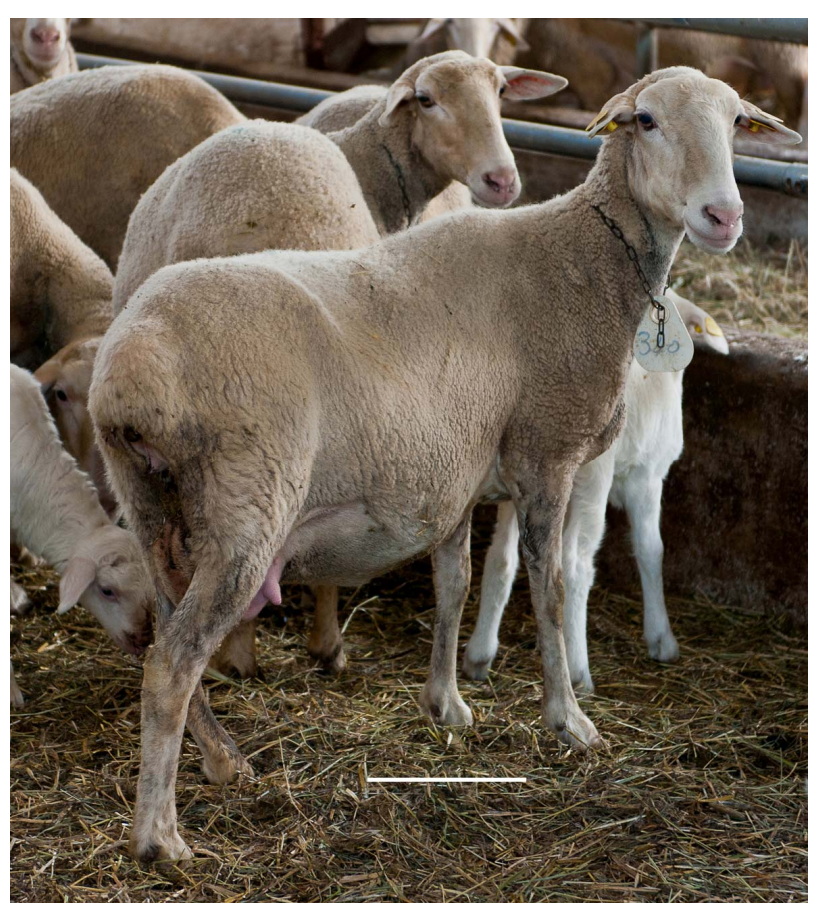

Figure 2. The "Laticauda" sheep breed. Bar $=21 \mathrm{~cm}$.

normally present in the male, triangular, spiraling up and to the side, absent in females. The neck is medium size, muscular, especially in the male. The trunk is well developed, strong bones, wide chest, ribs well arched and belly of medium size. The limbs are high but robust, large joints and dark claws. In the female, the breasts are large, well attached, with thin skin and nipples apart. The typical characteristic of the breed concerns the shape of the tail which is broad and thick at the base, sometimes even 20 cm long or more, which extends thinned up to the hock. The fleece, compact and with trunk-conical tufts, is white and covers the entire body, except the sternumabdominal region, the face and the lower half of the limbs, sometimes also the neck and shoulder regions. More or less intense pigmentation may be present, russet and black, especially the ears and cheeks, but rarely on the fleece.

Production. As reported above, it is a dual-purpose breed (meat and milk). It has good fertility, with a percentage of twin-ship not less than $75 \%$ with no rare triplets or quadruplets. Milk production from selected sheep can reach 1.5 to 2 liters daily. The calving period of about seven months and rational rotation calving within the flock have led to a steady production of milk during the year, thus promoting an effective and continuous marketing of the product. In terms of composition, Laticauda sheep's milk has a fat content of $7 \%$ - 13\%, protein $5.5 \%$ $8.5 \%$ and dry matter of $20 \%$ - $25 \%$. A valuable product of the cheese-making process with Laticauda milk is "pecorino Laticauda Sannita”, marketed fresh or dried (Figure 3), in various sizes and shapes of yellow-orange. Cheese ripening takes place only in rattan baskets called "canestre", about $20 \mathrm{~cm}$ in diameter and $12 \mathrm{~cm}$ in height, a practice linked to reduced availability of milk for both small flocks of Laticauda and the habit To use the most part of the milk produced for feeding the lambs. In 2004 the application for registring the PDO "Pecorino di Laticauda Sannita” was sent to the Ministry of Agriculture and Forestry by the Organizing Committee consisting of Provincial Breeders Associations of Avellino, Benevento and Caserta, and local processors.

\subsection{Bagnolese Sheep}

Origins and diffusion. The Bagnolese ewes, also called Malvizza, take the name from the town of Bagnoli Irpino (province of Avellino). The race, as a result of cross-breeding and hybridization in which we can recognize the facial features of Barbary sheep, is distributed mainly in the area of Campania, in the Mountains of Picentini, Alburni, Vallo di Diano, the plain of the Sele river and, marginally, in the hills of Caserta and Benevento provinces.

Population. In the 1980s the population was estimated to be 20,000 head; its numbers have recently declined greatly.

Breeding. The animals are kept in small and mediumsized flocks (50 - 400 head) rarely consisting of only Bagnolese breed, due to the simultaneous presence of hybrid animals or other breeds. In the past, the prevailing farming system, family-owned and away from the large urban settlements, was of a pastoral type where grazing was the main source of food: livestock farms have now converted to the semi-wild system with food integration (maize, barley, beans, etc.). In general, the animals are housed through the winter in simple but functional structures.

Morphological traits. The size is medium-large with the head rather light with a ram's profile (Figure 4), more pronounced in the male. The horns have a spiral shape and are sturdy; the ears are medium size, flat and droping flow. The neck is strong, well joined to the shoulder and withers. The trunk is long with a large chest. The back is inclined toward antero-posterior direction, shoulder well attached to the chest, back and loins broad, elongated and muscular abdomen of medium size. The tail, rather long, with a small developed lipoma at the base, starts from the 


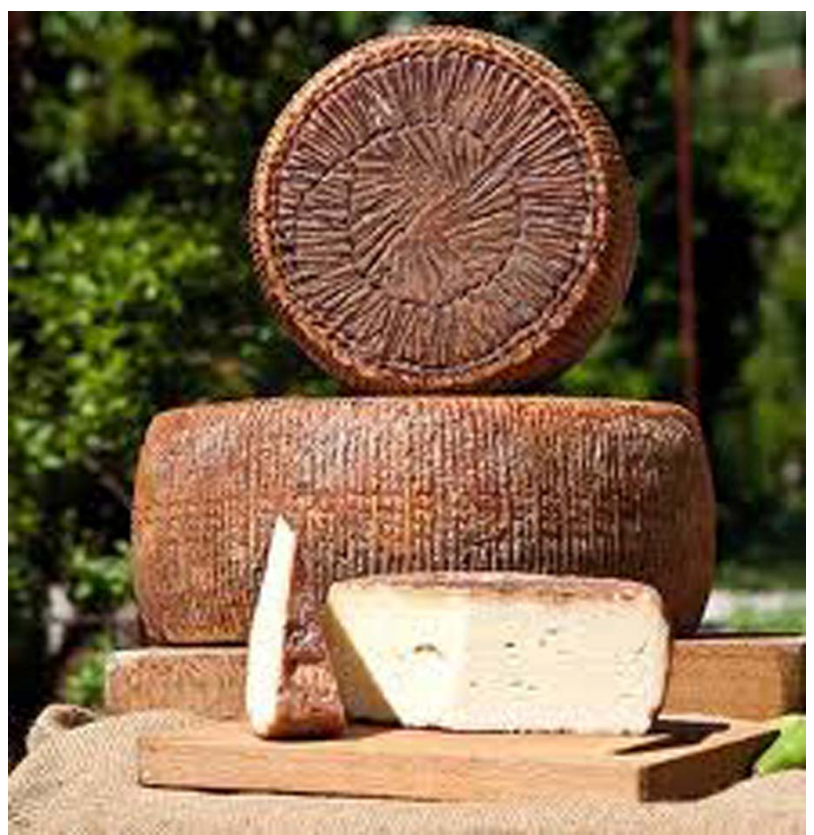

Figure 3. The "Pecorino" cheese.

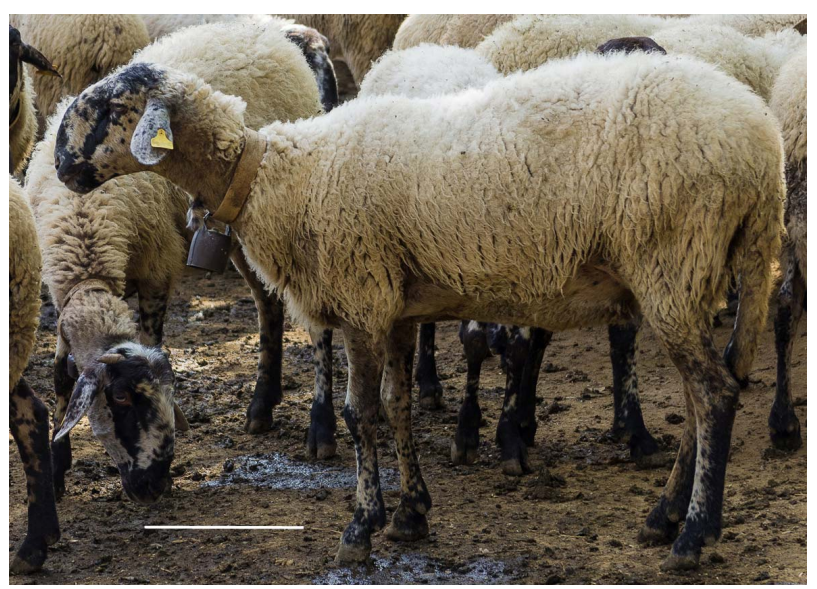

Figure 4. The "Bagnolese" sheep breed. Bar $=24 \mathrm{~cm}$.

upper third, and makes thinner to the hock. The udder is great with globose shape, soft and elastic tissues and clearly defined teats. The limbs are long, strong, lean, with dark-gray and well-shaped claws. White fleece consisting of conical tufts completely covers the body with the exception of the ventral side of the lower region of the neck, head and limbs. The head, neck and limbs are typical of black speckling that, in some individuals, may be large black spots. The skin is elastic and light pink.

Biometric and reproductive characters. On average, the Bagnolese sheep is $74.5 \mathrm{~cm}$ high at the withers; the trunk is $82.3 \mathrm{~cm}$ long, the chest is 32.8 high and has a circumference of $94.6 \mathrm{~cm}$. The weight is on average $58 \mathrm{~kg}$ in ewes and $95 \mathrm{~kg}$ in rams. This breed has good fertility, with a high percentage of twins and triplets not being rare.

Production. Bagnolese lambs are typically fed exclu- sively with breast milk, which helps make their meat very tender and delicate. The milk is rich in protein and very suited to cheese-making. It is the raw material to produce excellent pecorino and ricotta cheese.

\subsection{Cilentana Goat Breed}

Origins. This breed is present in the province of Salerno, in particular in the "Cilento and Vallo di Diano" National Park, the only Italian National park elected as "World Biosphere" from UNESCO for the richness of plants and animals. The numerical consistence is about 4000 heads, raised still essentially with traditional methods, with extensive use of wild-grazing or semi-wild grazing. In this population, one can still find a few examples related to the phenotype commonly called "Goat Cilento" which is now differentiated in three subgroups by the color of the coat: black, tawny and gray.

The consistency. In the early 70s the numerical strength of this breed only on the territory of the Salerno province was about 5000 heads, considered a small number when compared to the widespread that this breed has had in the past. Over the past thirty years, this situation has under-gone a further decline and today there are just over 150 heads for each subgroup present in the birth register.

The breeding. Subgroups Goat Cilento Tawny and Gray are most common in areas characterized by low hill pastures, more productive and more easily accessible, while the subgroup of black color is prevalent in areas of high hills and mountains and in Mediterranean area pastures which are more difficult to access and less productive. The consistency of the herds ranging from a few units to 80 - 100 heads maximum, often mixed with other ecotypes and/or other species. The farming system is wild or semi-wild type even if sedentary, with extensive use of the pasture.

Morphological characters. Cilentana Tawny Goat is of medium size with a live weight of 55 - $60 \mathrm{~kg}$ in rams and of 40 - $45 \mathrm{~kg}$ in females. It has a small head, horns present in $35 \%$ of subjects, mainly of Alpine type (such as saber curve backwards), 20 - 30 cm long, or even Type Garganic (facing backwards, with tip helical and directed towards the outside) $30-40 \mathrm{~cm}$ long. The ears are pendant semi lateral or horizontal, the slope is present. The coat is fawn-colored uniform. The hair in males is mainly one long, while females can only be a long, long, short or just short.

Cilentana black goat (Figure 5) is of medium size. It has a small head, the horns present in $60 \%$ of heads of both sexes, are mainly made of "Garganic" type, 30 - 40 $\mathrm{cm}$ long or even of "Alpine" type $20-30 \mathrm{~cm}$ long. The ears are pendant semi-lateral or horizontal, the slope is present. The coat is black uniform. The hair in males is mainly long, while in females it can only be long or short and long.

Goat Cilento gray is of medium to large size with a live 


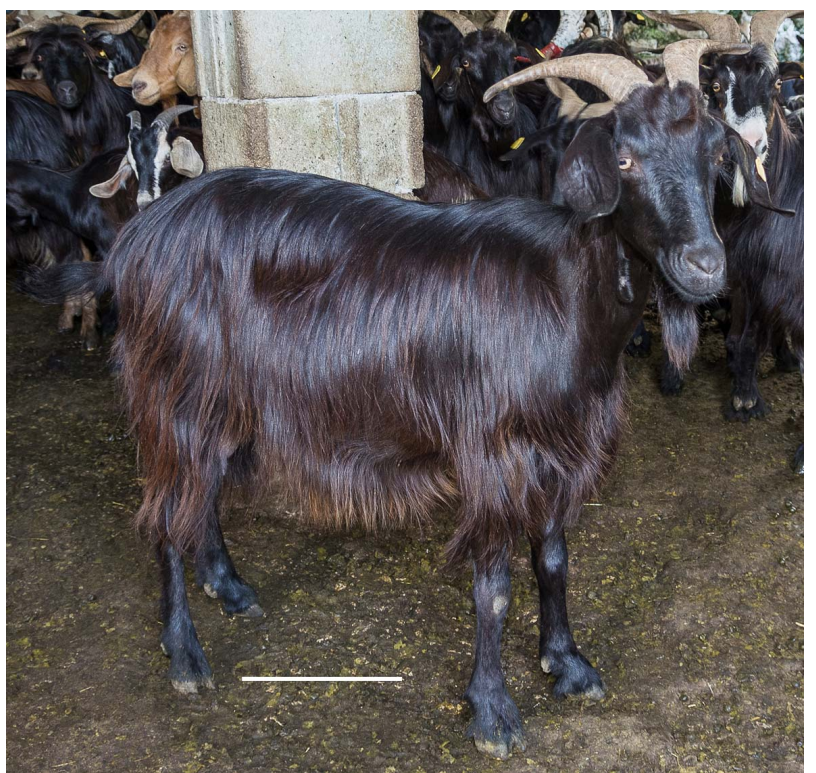

Figure 5. The “Cilentana” black goat breed. Bar $=20 \mathrm{~cm}$.

weight of 65 - $70 \mathrm{~kg}$ and 45 - $50 \mathrm{~kg}$ in males and females, respectively. It has a small head, horns present in about half of the subjects, mainly of Alpine type, $20-30 \mathrm{~cm}$ long or of type Garganic type, 30 - $40 \mathrm{~cm}$ long.

The ears are semi pending side, the slope is present. The coat is usually gray uniform with shoulder, neck and back darker. The hair in males is mainly long, while females can only be long or short and long.

The productions. Despite the Goat Cilento is a dualpurpose breed (milk and meat), its breeding is aimed mainly for meat production, as a kid light, and only a small part in the production of cheese. In particular, it produces almost exclusively the ricotta cheese (Figure 6), a cheese dairy production southern symbol, the name of which comes from the technique of coagulation of milk, obtained in part by rennet (like cheese) and partly by thermal process (as for the ricotta).

Diffusion. It is raised in Campania region (Provinces of Caserta, Naples, Avellino, Benevento, Salerno); Lazio region (provinces of Latina and Frosinone); Molise region (province of Campobasso).

\subsection{Casertana Pig Breed}

Local names are also "pelatella, napoletana, teanese”.

Origin. During the early I century DC, in Campania region, country Latins told about a black pig without bristles, the likely ancestors of Casertana breed. Like all swine widespread in Italy islands and peninsula, Casertana breed results from roman pig (porco romanico), a middle form between Sus europeus and Sus indicus.

Performance. At the age of one year the weight is 130 - $140 \mathrm{Kg}$, at 1.5 years it is $160 \mathrm{Kg}$ and $260 \mathrm{Kg}$ when older. Sows are fertilized at the age of 7 - 8 months, ges- tation length is about 110 days, and typical litter size at birth is 6 , rarely 9 - 10 .

Morphology. It's a very rustic breed, suitable for wild or half-wild farming with fattening trend. It's of little size and solid skeleton; medium developed head with truncated conical shape and straight front-nasal profile or slightly concave, long and thin grunt; ear are of medium size, close-up and hanging forward; the neck is prolonged and narrow, elongated and narrow body, backlumbar line slightly convex, sloping back, light shoulders, slightly convex thigh; twist tail, thin and lean limbs of medium length. The colour is black or slate-grey skin (Figure 7); sparse and thin bristles, sometimes they are grouped in tufts above all on neck, head and at the tip of the tail. In the past they were distinguished three types: small type also called of "Teano", with a withers size 60 - $65 \mathrm{~cm}$; large type with a withers size $70-75 \mathrm{~cm}$; and a medium type. According to our biometric data, withers size is $90-95$ in the boar and $80-85 \mathrm{~cm}$ in the sows. Special formations called "tettole", also called "bargiglioni" are present at the parotid region.

Uses. Its meat is particularly suited for processing or

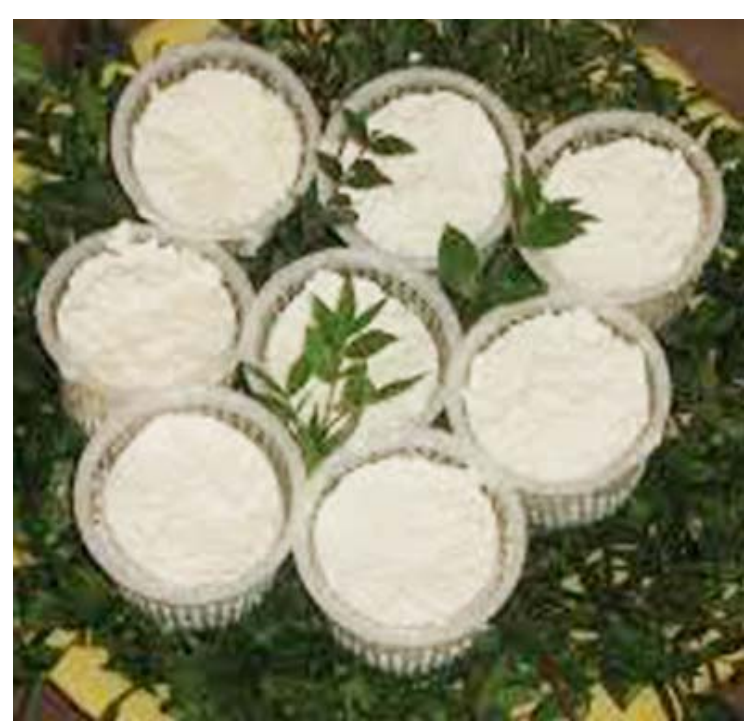

Figure 6. The "Ricotta" cheese.

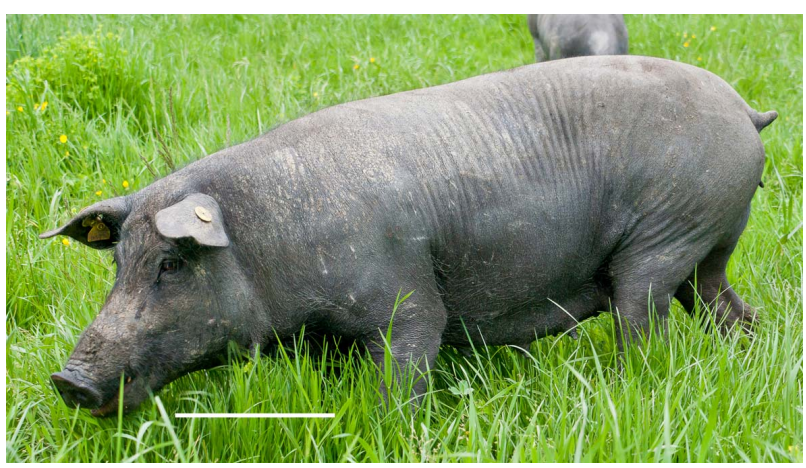

Figure 7. The "Casertana” pig breed. Bar $=40 \mathrm{~cm}$. 
direct consumption.

Consistency. In 2012 the birth register maintained by the National Swine Breeders (ANAS) reported a total of 357 sows and 30 boars in 23 farms located mainly in Caserta province.

\subsection{The Napoletano Horse Breed}

Origins. Campania felix, the plain that stretched from Volturno and Sarno rivers, currently corresponding to part of Caserta and Naples provinces, has always been, because of its specific climatic and geo-pedological characteristics, a suitable area addressed to horse-breeding. In fact, already the Etruscans people chose this area to establish their horse herds, behind the Greek settlements of the Phlegrean coast, in Capua, where later the Romans raised the best examples of horses for the imperial court. The advent of the Maritime Republic of Amalfi allowed imports of Turkish horses which were crossed with the Campania horses to perform the basis for the emergence of the Neapolitan horse, appreciated firstly as indigenous breed and then as a true breed. The noble knight Neapolitan Giovan Battista Caracciolo did not spare himself in praise for these horses which showed their greatness at the walk, canter, traveling and jumping into battle. In the fifteenth century, Ercolani writes: "The Neapolitan horses enjoyed the highest reputation as war horses". Unfortunately, the early 900 mark the beginning of the decline of this breed as reported by Mascheroni [4] and Fogliata [5].

Consistency and breeding area. To date, the number of individuals enrolled in the Birth Register is 10 mares and 4 stallions. It's raised exclusively in the Campania region, in particular in the province of Naples.

The characteristics. It has a bay coat burnt chestnut, gray and blackish (Figure 8), proud head, square, with a broad forehead and large eyes, a straight profile convex in the nasal tract and accentuated of alignment of the nostrils; the ears are small and mobile, the neck is muscular and long, elegantly arched, with thick mane and long; the shoulder is muscular, well laid back, long and firmly attached to the trunk; the withers are big, high, including in the large base of the neck; at 42 months the minimum height is $1.50 \mathrm{~m}$; the back is collected, wide and rounded; the chest is broad and deep; the limbs are proportionate and muscular.

Attitude. The morphological conformation makes suitable the horse to pull the saddle and medium light, particularly in the discipline of dressage and of high school.

\subsection{The Salerno Horse Breed}

Origins. The Salerno horse has its origin in the Sele river plain, flat wide geographical area, bounded on the north by the southern foothills of the Picentini mountains, to the east by Sele river valley and to the south by the findings of the Sub-Lucan Apennines. This area was suitable for horse breeding since the time of the Roman empire. The Salerno horse today acknowledges the influence of many races, initially the Neapolitan, Andalusian, Norman and horses of eastern origin that gave him great strength, toughness and harmony in form, making it particularly suitable to the saddle and to the service of the carriage. Then, the intersection with the Thoroughbred awarded him morphfunctional and valuable ideal for equestrian sports.

Breeding area. It's raised exclusively in the Campania region, particularly in the provinces of Salerno (18 farms), Caserta (4 farms) and Naples (1 farm).

Consistency. Currently, the birth register of Salerno horse was merged with that of the Persano horse and in total are enrolled 91 mares, 35 stallions and 146 foals (94 females and 51 males). In particular, refer to the Salerno horse 46 mares, 23 stallions and 79 foals (53 females and 26 males).

Morphological characters. It has a bay coat (Figure 9), black, gray and chestnut rarely, conical head with a straight profile, the neck is proportionate not overly muscled; the shoulder is sturdy and well attached to the trunk; the croup is slightly sloping; the chest is developed and muscular; the limbs are sturdy. The minimum height at the withers is $150 \mathrm{~cm}$ in both males and females.

Attitudes. In the past it was used as a gallop breed, racing obstacles and show jumping competition; today, with a suitable program of selection and genetic improvement, it could regain its place in equestrian sports and, with his nature quiet, balanced and energetic, it could be used in the horse-therapy.

\subsection{Persano Horse Breed}

Origins. It was known in the past as Government breed of Persano Municipality, it has its cradle in the plain ex-

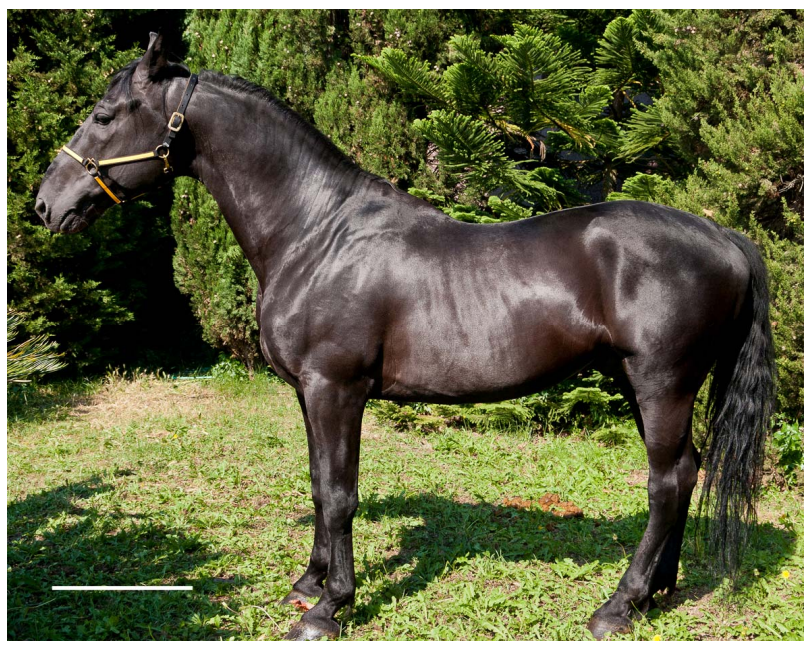

Figure 8. The "Napoletano" horse breed. Bar $=50 \mathrm{~cm}$. 


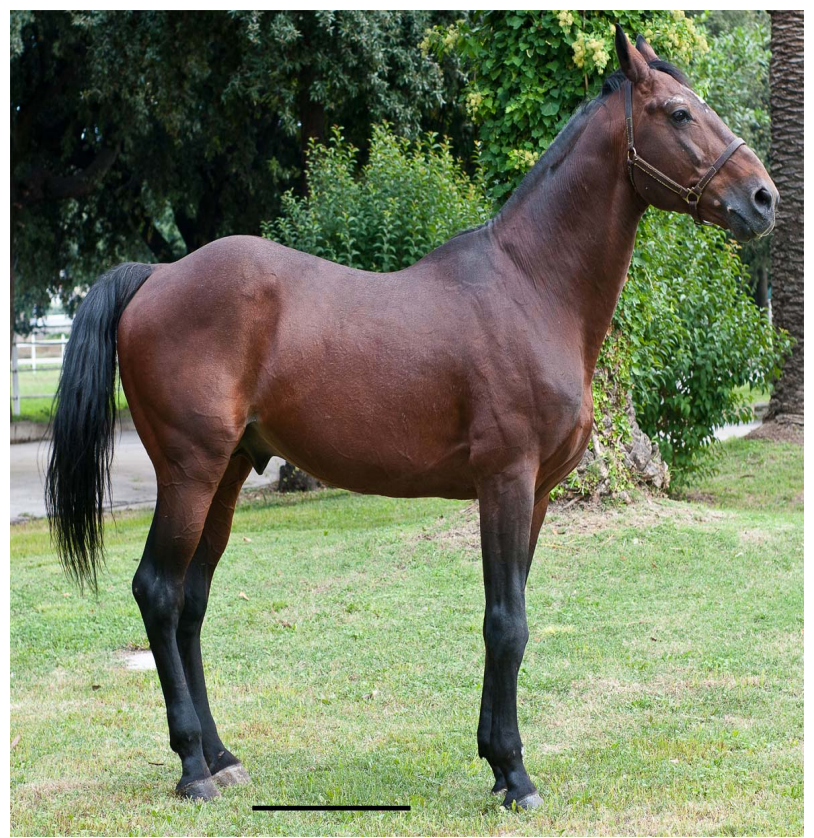

Figure 9. The "Salernitano" horse breed. Bar $=50 \mathrm{~cm}$.

tending between the Sele and Calore rivers, in the Salerno province. Indigenous breeds, raised during the feudal times in wooded areas and marshes of Persano village, have substantially contributed to the selection of this breed. It was Charles III of Borbone in 1730 who decided to breed in the Persano village a horse breed suitable for both parade and war. In 1741, four Arab stallions, a gift of the Ottoman Ambassador Husseyin Efend were to the King of Naples, were used as reproducers. Later, in 1829, mares of the oriental type, were crossed with Andalusian stallions in order to introduce a touch of royalty to action. The clever work of the Borbone king and the technical capabilities of their breeders led to the selection of a horse with great anatomical traits and character, with a shoulder height of about $145 \mathrm{~cm}$, and a head alters square, a round rump, with robust limbs and gait detected. Unfortunately, to the throne of Frederick II of Borbone and his choice to use the Prussian stallion breed Meklenburg to increase the size, marks the beginning of the decline of the breed also for the appearance of genetic defects and reduced fertility. In 1860, the horse breeding of Persano goes to the Italian State which did nothing to recover the breed. In 1874 the minister of war Ricotti abolished by a decree the Persano horse despite this breed counted 356 specimens (including 187 breeding females) and some of them were transferred to the Cavalry Regiments, partly sold to breeders of Salerno. In 1900, by act No. 221 of 14 November, the minister of war reconstituted the Government breed of Persano, establishing a group of 78 mares which in morphology, type and attitude reminded the ancient breed of Persano and were divided into two different groups: one received blood from eastern horse and the other one received blood from English horses. In the 1930 the need to produce suitable subjects useful for horse competitions led to a core group of mares of different origin with strong jumping ability and crossed only which male thoroughbred. After 1945 the horse Persano changes intended use: no more war horse, but sport horses.

The consistency. Currently, as before reported, the birth registry of Salerno horse was merged with that of Persano and in total are enrolled 91 mares, 35 stallions and 146 foals (94 females and 51 males). In particular, refer to the Persano horse 45 mares, 12 stallions and 67 foals (41 females and 25 males).

The characteristics. The Persano horse is $160-165 \mathrm{~cm}$ high at the withers. It has a bay coat, chestnut, gray or blackish; it has a well proportioned head with broad forehead, large eyes and bright, straight profile, round jaw, ears and short spaced; it has long and muscular neck, slightly arched, with thick and long mane; the shoulder is long and well laid back; the croup is short, muscular and sloping with bushy and long tail; broad and deep chest, sturdy limbs, but fine.

Attitudes. In the past it was used as a war horse, now it has good aptitudes for riding, complete, dressage and high school. It has a docile and courageous temperament.

\section{AIMS OF PROJECT "RARECA"}

The overall objective of the project is to support and encourage the development of agro-livestock rearing linked TGA of Campania region identified through targeted measures and sustainable agro-environmental terms. The project specifically arises, in all groups of species/breeds included in the notice the following points: 1) maximization of the population and minimization relationship between the reproducers, with the aim to increase immediately the population through the use of biotechnology of reproduction and selecting, for each generation, breeding to reduce its consanguinity coefficient; 2) identifications of the characteristics of the TGA, the farming system and qualification of local products; 3 ) cytogenetic analyses to select animals (especially the male reproducers) which are free of chromosome abnormalities (Figure 10) [6-9] or with unbalanced sperms or embryos [10,11]; 4) genetic analyses to study the variability of genes that influence the qualitative and quantitative characteristics of the breed and health of the products; 5) biochemical approaches to study some polymorphic protein associated to the breed and products $[12,13]$; 6) the need to adopt rationing schemes tailored to real nutritional needs of different TGA, in order to improve animal welfare and the ability to characterize the productions from the qualitative point of view, through the use of analysis of microbiological, chemical, and molecular sensory; 7) the identification of breeding stock, through the analysis of their DNA; 8) 


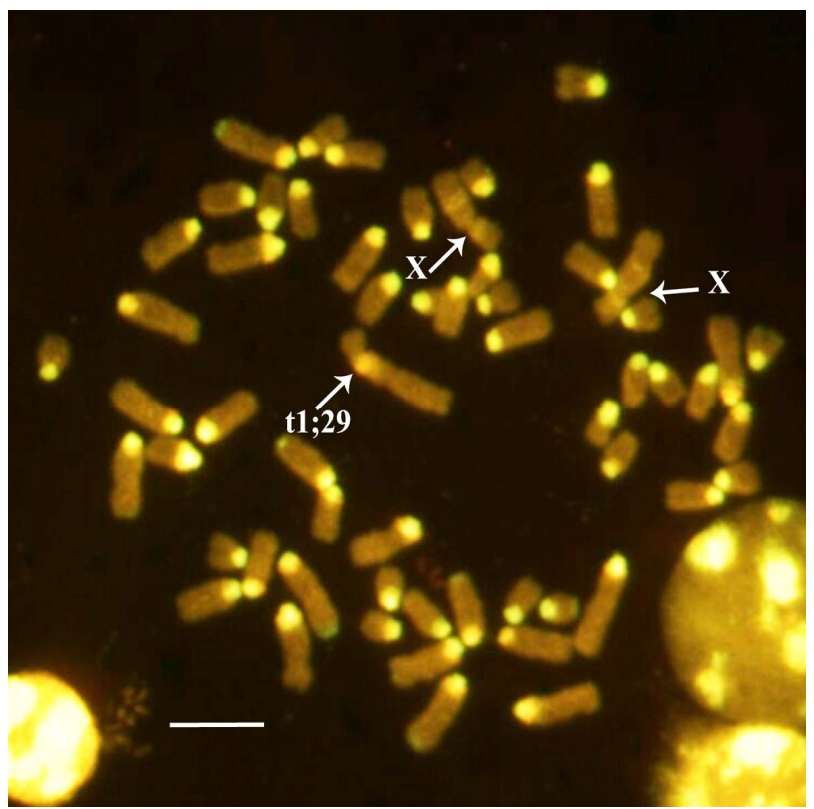

Figure 10. Metaphase plate obtained from a female Agerolese cattle heterozygous carrier of rob (1:29) and treated for CBAbanding technique. The translocated chromosome and the two $\mathrm{Xs}$ are arrowed. Slides with chromosome preparations were treated in barium hydroxide and then in 2xSSC, stained with acridine orange $(0.1 \%$ in P-buffer), mounted in P-buffer with coverslip and finally observed under a fluoresce microscope (Nikon E-1000) connected with a coupled camera and PC. Bar $=10 \mu \mathrm{m}$.

creation of a network with dissemination and transfer of results, through training and updating of farmers, workers and consumers of livestock sectors, the main issues addressed in previous actions.

\section{DISCUSSION}

The region of Campania has a very diverse livestock system in which the greatest opportunities are offered by typical high-quality products with a particular area of origin and special production and processing techniques, which play a major role in the local economy and production system. The same lines as the common agricultural policy and national level have highlighted the importance of quality production as a means to reduce surpluses and provide alternative income opportunities for the rural population, especially in mountainous and disadvantaged areas, and to meet the growing consumer demand for and safe products with quality characteristics unique to the origin and the particularity of the production processes, often linked in animal production-spoke-populations residual and/or endangered. Under these conditions the native breeds (TGA) in danger of extinction may be able to take action towing products and businesses, and are a driving force for the development of local economies. Each TGA is harmoniously integrated with its breeding environment, climate and flora that characterize it, the harmonious union of these conditions, together with the genetic characteristics inherent in the TGA, provides unique products (traditional products typed), prestige not repeatable elsewhere. As part of the enhancement of native animal germ plasma, it is essential to identify actions and sustainable agro-environmental terms. It will be necessary for this purpose the establishment of reproductive material and the DNA banks of the different TGA considering that, at the moment, they are absent. This is a crucial starting point for the development, in the longer term, of reproductive strategies to be used. It's essential for this purpose to increase the number of birds of each TGA in the area, through the application of innovative reproductive technologies such as artificial insemination (AI), the in vitro embryo production (IVEP), embryo transfer (ET) and the sexing of both sperms and embryos [14]. These biotechnologies should be also accompanied by intra-breed genetic characterization using molecular markers, such as the microsatellites [2] and next generation DNA sequencing technology [15].

The strategies suggested in the project RARECA are two: in situ and ex situ. In the former race is brought within the specific meat chain in its historical context and cultural landscape. In the latter it provides for the cryopreservation of genetic material in the form of gametes, embryos but also of DNA sequences, through the implementation of a bank of genomic resources (Genome Resource Banking).

The characterization of genes already known as well as the identification of new genes and new mutations with quantitative phenotypic effect on complex traits is a difficult challenge for the researchers, but today they have innovative research tools. The study of single genes can answer both basic questions such as the animal physiology, bio-diversity of livestock populations, their evolutionary history and mechanisms of adaptation to both application requirements such as the insertion of genes in breeding programs or the use of molecular information for diagnostic purposes, for example for the traceability of animal products. The study of protein variants is of great interest in the study of diversity that characterize the various breeds. A simple amino acid substitution, in fact, can have a direct effect on the functional characteristics of the protein itself, with possible modifications of the underlying physiological properties and adaptive animal. The use of integrated procedures of mass spectrometry, chromatography and isoelectrofocusing, able to determine variations in the mass, hydrophobicity and charge of the species analyzed, has long been used to highlight amino acid substitutions in proteins essential to the life of the animal. Therefore, comparative studies of blood, milk and semen proteins of the different TGA with other breeds most numerically significant are necessary to march the differ- 
ences of TGA $[12,13]$. In order to improve animal welfare and, consequently, to guarantee high quality standards of the food they provide, rationing schemes tailored to real nutritional needs of different breeds and/or strains of interest must be done. In fact, a positive placement on the market of their products is only possible through a characterization of the dietetic-nutritional peculiarities and organoleptic characteristics of products. However a high degree of specialization in all stages of the productions and basic diets to improve the quality of food animals is required to achieve those goals.

\section{ACKNOWLEDGEMENTS}

This study was supported by "PSR, Misura 214-e2, Conservazione e Valorizzazione di Animali allevati in Campania e in via di estinzione”, and project "Razze Autoctone a rischio di estinzione della Regione Campania” (RARECa).

\section{REFERENCES}

[1] FAO (2007) The state of the world's animal genetic resources for food and agriculture. Food and Agriculture Organization of the United Nations, Commission on Genetic Resources for Food and Agriculture, Rome.

[2] Dumasy, J.-F., Daniaux, C., Donnay, I. and Baret, P.V. (2012) Genetic diversity and networks of exchange: A combined approach to assess intra-breed diversity. Genetic Selection Evolution, 44, 17. doi:10.1186/1297-9686-44-17

[3] Notter, D.R. (1999) The importance of genetic diversity in livestock populations of the future. Journal of Animal Science, 77, 61-69.

[4] Mascheroni, E. (1927) Zootecnica speciale. UTET, Torino.

[5] Fogliata, G. (1910) Tipi e razze equine, Editrice, Mariotti.

[6] Iannuzzi, A., Perucatti, A., Genualdo, V., De Lorenzi, L., Peretti, V., Di Berardino, D., Parma, P. and Iannuzzi, L. (2012) Two new reciprocal translocations in sheep (Ovis aries, $2 \mathrm{n}=54)$. Chromosome Research, 20, 791.

[7] Iannuzzi, A., Perucatti, A., Genualdo, V., De Lorenzi, L., Di Berardino, D., Parma, P. and Iannuzzi, L. (2013) Cy- togenetic elaboration of a novel reciprocal translocation in sheep. Cytogenetic and Genome Reseach, 139, 97-101. doi:10.1159/000346193

[8] De Lorenzi, L., Genualdo, V., Gimelli, S., Rossi, E., Perucatti, A., Iannuzzi, A., Zannotti, M. Malagutti, L., Molteni, L., Iannuzzi, L. and Parma P. (2012) Genomic analysis of cattle rob (1;29). Chromosome Research, 20, 815-823. doi:10.1007/s10577-012-9315-y

[9] Perucatti, A., Genualdo, V., Iannuzzi, A., Peretti, V., Di Berardino, D. and Iannuzzi, L. (2012) Cytogenetic survey in endangered domestic species reared in southern Italy. Chromosome Research, 20, 785.

[10] Pauciullo, A., Nicodemo, D., Peretti, V., Marino, G., Iannuzzi, A., Cosenza, G., Di Meo, G.P., Ramunno, L., Iannuzzi, L., Rubes, J. and Di Berardino, D. (2012) X-Y aneuploidy rate in sperm of two "minor" breeds of cattle (Bos taurus) by using dual color fluorescent in situ hybridization (FISH). Theriogenology, 78, 688-695. doi:10.1016/j.theriogenology.2012.03.017

[11] Rubessa, M., Iannuzzi, A., Peretti, V., Pauciullo, A., Cosenza, G., Ramunno, L., Iannuzzi, L., Rubes, J. and Di Berardino, D. (2012) Mitotic index and aneuploidy variation in growing day 2-to day 7-IVP bovine embryos of the Agerolese breed of cattle. Chromosome Research, 20 , 795.

[12] D’Ambrosio, C., Novi, G., Salzano, A.M., Ledda, L. and Scaloni, A. (2012) Screening for $\mathrm{Hb}$ polymorphism in autochthonous animal breeds from Campania region (Southern Italy): The case of Laticauda sheep, Nero casertano pig, Napoletano, Salernitano and Persano horses. ITPA2012, Cost Workshop, Farm Animal Proteomics, Viterbo, 12-15 Giugno 2012, 63.

[13] Salzano, A.M., Novi, G., D’Ambrosio, C. and Scaloni, A. (2012) Hemoglobin polymorphisms in the native cattle breed Agerolese from Southern Italy. ITPA2012, Cost Workshop, Farm Animal Proteomics Viterbo, 12-15 Giugno 2012, 65-66.

[14] Andrabi, S.M.H. and Maxwell, W.M.C. (2007) A review on reproductive biotechnologies for conservation of endangered mammalian species. Animal Reproduction Science, 99, 223-243. doi:10.1016/j.anireprosci.2006.07.002

[15] Shendure, J. and Ji, H. (2008) Next-generation DNA sequencing. Nature Biotechnology, 26, 1135-1145. doi:10.1038/nbt1486 